УДК 780.616.31.071.2 (438) (092) : 78.032

DOI 10.34064/khnum2-1717

\title{
Коденко I. I.
}

ORCID 0000-0003-3579-2709

Харківський національний університет мистецтв імені І. П. Котляревського, 61003, майдан Конституиії, 11/13, м. Харків, Україна

\section{Концепції відтворення старовинної музики у творчості Ванди Ландовської}

\section{АНОТАЦІЯ - Коденко І. І. Концепції відтворення старовинної} музики у творчості Ванди Ландовської. - Стаття має на меті виявлення особливостей погляду видатної польської клавесиністки В. Ландовської (1879-1959), що стояла у витоків автентичного руху в музичному виконавстві, на інтерпретацію старовинної музики. Дослідницьким матеріалом, насамперед, $є$ нотатки артистки, доступні у російському перекладі А. Майкапаpa (1991). 3 огляду на світову славу В. Ландовської, аналізу іiі виконавського 
стилю приділено недостатньо уваги у спеціальній літературі. Між тим, розквіт автентичного напряму виконавства та поширення відповідної проблематики в музикознавстві в останні часи робить такий розгляд актуальним, так само, як і вивчення досліджень та записів В. Ландовської, котрі ще чекають свого часу.

Торкаючись рис барокової музики, необхідних для розуміння ії інтерпретації В. Ландовською, стаття звертається до питань виконання творів минулого на історичному клавесині (темпи, динаміка, артикуляція, фразування, регістровка, розшифровка прикрас, інтонування), як їх бачила видатна артистка, наголошуючи на необхідності вивчення сучасними музикантами старовинних інструментів і теоретичних трактатів давніх майстрів. Саме таке вивчення підштовхнуло В. Ландовську до висновку: виконавське мистецтво минулого не обмежене «техніками», але $\epsilon$ «координацією думки та пальців». Вихований музичний смак і вірно сформовані слухові образи спрямовують і розвиток необхідних інтерпретаторові технічних навичок. Популяризуючи клавесин, вона досконало ревізувала усталені уявлення свого часу про музику минулого. Колосальний досвід В. Ландовської-клавесиністки є необхідним сучасним виконавцям, що обумовлює перспективність подальшого поглибленого вивчення спадку видатної артистки й дослідниці. - Ключові слова: відтворення старовинної музики у творчості Ванди Ландовської, Бароко, клавесин, автентичне виконавство, індивідуальний виконавський стиль, конщепиія.

\section{АННОТАЦИЯ - Коденко И. И. Концепции воссоздания старинной} музыки в творчестве Ванды Ландовской. — С Сатья имеет целью выявление особенностей точки зрения выдающейся польской клавесинистки В. Ландовской (1879-1959), стоявшей у истоков аутентичного движения в музыкальном исполнительстве, на интерпретацию старинной музыки. Исследовательским материалом, прежде всего, стали заметки артистки, доступные в русском переводе А. Майкапара (1991). Учитывая мировую славу В. Ландовской, анализу её исполнительского стиля в специальной литературе не уделено достаточного внимания. Между тем, расцвет аутентичного направления исполнительства и расширение соответствующей проблематики в музыковедении в последнее время делает такое рассмотрение актуальным, так же как и изучение исследований и записей В. Ландовской, которые ещё ждут своего часа. 
Касаясь черт барочной музыки, необходимых для понимания её интерпретации В. Ландовской, статья обращается к вопросам исполнения произведений прошлого на историческом клавесине (темпы, динамика, артикуляция, фразировка, регистровка, расшифровка украшений, интонирование), как их видела выдающаяся артистка, подчёркивавшая необходимость изучения современными музыкантами старинных инструментов и теоретических трактатов старых мастеров. Именно такое изучение подтолкнуло В. Ландовскую к выводу: исполнительское искусство прошлого не ограничено «техниками», но предстаёт как «координация мысли и пальцев». Воспитанный музыкальный вкус и верно сформированные слуховые образы направляют и развитие необходимых интерпретатору технических навыков. Популяризируя клавесин, артистка детально пересматривает устоявшиеся представления своего времени о музыке прошлого. Колоссальный опыт В. Ландовской-клавесинистки необходим современным исполнителям, что обусловливает перспективность дальнейшего углублённого изучения наследия выдающейся артистки и исследовательницы. - Ключевые слова: воссоздание старинной музыки в творчестве Ванды Ландовской, Барокко, клавесин, аутентичное исполнительство, индивидуальный исполнительский стиль, концепциия.

\section{ABSTRACT - Kodenko I. I. Concepts of Early Music Re-creation in}

\section{Wanda Landowska's Work.}

Background. The XIX century presented the world with many wonderful musicians, among them there is Wanda Landowska (1879-1959), a researcher of the musical culture of the past. She is considered as one of the founders of the authentic movement in academic musical art, a representative of the first generation of "historical performers" who returned long-forgotten ancient music to their contemporaries. Landowska's creativity, whose concerts with historical programs in the early XX century enjoyed extreme popularity, was covered in the press of that time, and, after, in special literature, although, given the world fame of the artist, clearly not enough. The name of W. Landowska is mentioned in passing by her contemporary A. Schweitzer in his famous monograph "J. S. Bach" (Schweitzer, 1965, transl. from German Ya. Druskin, p. 259); the review articles by famous Russian musicians and scientists A. V. Ossovsky (1971) and A. Maikapar (1991) are devoted to her. However, the fundamental studies of all aspects of W. Landowska's activity are still lacking both in foreign and in domestic musicology. Ukrainian 
scientists have already taken certain steps in the study of the work of an outstanding Polish artist. G. Kurkovsky (1983) highlights the performances of a harpsichordist in Kiev, analyzing her repertoire. As a participant in concerts of the Imperial Russian Music Society, between 1907 and 1911 W. Landowska performed with constant success in Ukraine, not only in Kiev, but also in Odessa and Kharkiv. The researches by N. Svyrydenko, which appeared in the last decade (2010a, 2010b, 2017), gives a due assessment of the activity of the outstanding Polish musician in promoting ancient music. However, in general, in publications devoted to the artist, an analysis of the features of her performing style was not given enough attention, as well as her research works and notes.

Objectives. This article aims to identify features of the concepts of W. Landowska regarding the performance of ancient music. The research material was, first of all, the notes of the outstanding harpsichordist collected by her student D. Restout; Russian translation by A. Maikapar (Landowska, W., 1991).

The results of the study. Landowska is one of the firsts who was involved in the formation of the phenomenon of "early music". She draws attention to the fact that few of her contemporaries carefully studied the music of the Middle Ages, Renaissance, Baroque. Meanwhile, the musical practice of these eras lays the foundation for the formation of styles and Viennese classicism, and Romanticism, and new music. Working on the interpretation of ancient works, Landowska, first of all, proceeded from the historical context of the era and the general musical meaning. She emphasized the importance of playing music on the instruments of the exact era for which they were written. In her works, Landowska focused on the problems of reproducing ancient music on the harpsichord, namely, on such performance parameters as tempo, dynamics, registration, phrasing, ornamentation. In particular, Landowska presents and parses the tables of F. Couperin, J. Ph. Rameau and J. S. Bach with decipherments of ornamentations, touching in this connection also to issues of improvisation.

Landowska laid the foundations of historically informed performing, emphasizing the need for musicians to study the treatises of P. F. Tosi-J. F. Agricola, J. J. Quantz, F. Couperin, J. Ph. Rameau, L. Mozart, G. Frescobaldi, F. W. Marpurg, C. Ph. E. Bach. Relying on the old treatises, she sought to find a practical solution to the problems of interpreting ancient music precisely on authentic instruments, since the technique and character of the performance largely depend on the construction of the latter. Landowska studied in detail the clavier works of the 
outstanding harpsichordists F. Couperin and J. Ph. Rameau, and also paid great attention to the issue of the influence of French music on German music.

Landowska believed that in order to find the right tempo, high-quality sound, it is necessary to thoroughly study the mechanism of the instrument. We can talk about the "sense of rhythm", "accuracy and articulation of sound" about "spatial representations" only from the position of the harpsichordist, since the latter can have just different principles of intonation on the instrument and completely different decisions for fingering, than the pianist, due to the different construction of the harpsichord and piano (for example, without the passing of one finger under another).

Landowska deals with the main key to ancient music - rhetoric. Increased attention in interpretation should be given to phrasing and breathing, which plays a major role, since each pause, caesura logically share a melodic line. At the same time, rhythmic freedom should not become synonymous with arbitrariness Landowska's playing was always distinguished by rhythmic accuracy, with which it conveyed the duration of sounds. "Some phrases within the play require rhythmic changes, while others - do not," notes the artist (1991, p. 373).

Thus, Landowska insisted on a completely different approach to the interpretation of music of past eras compared to what reigned in her time. She believed that turning to the music of masters of the past gives the musician the opportunity to develop a good musical taste and aesthetic feeling, and studying of the theoretical sources of ancient eras - to create a full-fledged idea of ancient music. In order to embody his vision of music in sounds, the performer should have good taste, Landowska insists on this, but it must be connected with knowledge of the material, styles of the past and historical context. Studying old treatises, Landowska made certain conclusions: the technology of playing an instrument is more complex and multifaceted than simply polishing "complex passages", as it is considered today, and "coordination of thought and fingers" was called "technology" in that time (ibid., p. 150). In general, the artist puts "ears" and "consciousness" above just good finger coordination. The task of an authenticist is more difficult - it's not enough to have good technique, you need to be able to combine all other performance components: touché, rhythm, breath, agogics, ornamentation, rhetoric, symbolism, sound, timbre, etc.

Conclusions. W. Landowska positioned herself primarily as a harpsichordist, popularizing this instrument, although the sound of her harpsichord is still quite 
far from the sound of a "historical harpsichord", for example, G. Leonhardt. Nevertheless, the sound of the harpsichord recreated by Landowska made a stunning impression on his contemporaries. As a result, it completely changed the then performer's and listener's ideas about ancient music, giving a powerful impetus to a complete revision and rethinking of generally accepted manners of performing and romantic cliché of hearing. Fifty-year-old practical experience of Landowska-harpsichordist is very important for modern performers of ancient music, who strive for its most accurate reproduction, that open the perspectives for further in-depth study of the creative heritage of an outstanding artist. - Key words: early music re-creation in Wanda Landowska's work, Baroque, harpsichord, authentic performance, individual performing style, concept.

Постановка проблеми і аналіз публікацій за темою. XIX сторіччя подарувало світу багато чудових музикантів, серед яких - дослідниця музичної культури минулого Ванда Ландовська (1879-1959). Ïї вважають однією з основоположників автентичного руху, представницею першого покоління «історичних виконавців», які повернули сучасникам давно забуту старовинну музику. Доля Ванди Ландовської складалася не просто, але її стійкість і цілеспрямованість разом із величезним досвідом дослідження ренесансно-барокових джерел дозволили аргументувати необхідність вивчення старовинних інструментів, а також надали їй можливість осягнути унікальний світ автентизму.

Творчість В. Ландовської, виступи якої з історичними програмами на початку XX ст. користувалися надзвичайною популярністю, висвічувалась у тогочасній пресі, згодом, і у спеціальній літературі, хоча, зважаючи на світову славу артистки, й явно недостатньо. Ім’я артистки мимохідь згадує іiї сучасник А. Швейцер у своїй знаменитій монографії про I. С. Баха ${ }^{1}$ (Швейцер, 1965, пер. с нем. - Я. Друскин, с. 259), їй присвячені оглядові статті відомих російських музикантів-вчених А. В. Оссовського (1971), А. Майкапара (1991). Фунда-

\footnotetext{
${ }^{1}$ Вперше видана 1905 p.
} 
ментальних досліджень усіх аспектів діяльності В. Ландовської досі бракує як у закордонному, так і у вітчизняному музикознавстві. Закордонні джерела представлені, здебільшого, статтями у музичних словниках, як-то: Salter, L. (n. d.) в Grove Music Dictionary, Swain, J. P. (2013, с. 100-101, 140) в «Історичному словнику барокової музики» та інші подібні довідково-біографічні матеріали; досить стислою інформацією в історичних нарисах розвитку клавішних інструментів (Kottick, E., 2003). Українські вчені вже зробили певні кроки у дослідженні творчості видатної польської артистки: Г. Курковський (1983) висвічує виконавську діяльність клавесиністки у Києві, аналізуючи іiі тогочасний репертуар - як учасниця концертів Імператорського Російського Музичного Товариства, між 1907 та 1911 рр. В. Ландовська 3 незмінним успіхом виступала в України, окрім Києва, також в Одесі й Харкові (Свириденко, Н., с. 8). Дослідження Н. Свириденко, що 3'явилися у останнє десятиліття (2010a, 2010b), - статті до 130-річчя від дня народження й 50-річчя від дня смерті В. Ландовської - та монографія-підручник, присвячена виконанню творів I. С. Баха - дають належну оцінку діяльності видатної польської клавесиністки 3 пропаганди старовинної музики (2017, с. 6-10).

Однак в цілому в публікаціях, присвячених артистці, аналізу особливостей iіi виконавського стилю приділено недостатньо уваги ${ }^{2}$. Так само, як і їі дослідницьким працям та записам, котрі ще чекають свого часу.

Дана стаття має за мету виявити особливості концепцій В. Ландовської, що стосуються виконання старовинної музики. Матеріалом дослідження стали, насамперед, нотатки видатної клавесиністки, зібрані іiі ученицею Д. Ресту і видані у російському перекладі А. Майкапара (Ландовська, В., 1991).

Викладення основного матеріалу. Перше знайомство Ванди Ландовської зі старовинною музикою, що залишило по собі най-

${ }^{2}$ Взагалі, у піаністів-сучасників артистки не було прийнято багато говорити про різноманітність інтонування в музиці Бароко і віденських класиків; проте, процес досліджень виконавських проблем значно активізувався в останні роки. Так, наприклад, питання вивчення проблем інтонування в музичному виконавстві порушує Т. Б. Вєркіна (2008). 
яскравіше враження, відбулося ще в юності, коли вона почула відомий «Тамбурин» Ж.-Ф. Рамо у виконанні на фортепіано знаменитою Софії Монтер. Коли В. Ландовська перебувала у Парижі, іiї увагу привернула спадщина майстрів французького Ренесансу та Бароко ${ }^{3}$. Виконавицю вразило витончене високе мистецтво французьких майстрів XVII ст., виражене в лаконічності і вишуканості їх п’єс-мініатюр. В ці часи Париж обіймала аура знаменитих Всесвітніх виставок ${ }^{4}$, які відвідували аристократи і передова молодь; все навколо було пронизане духом «нового мистецтва», модерну, з його інтересом до історичного реконструювання, ретроспектив; цій всеосяжний творчий дух захопив і Ванду Ландовську. Ї̈̈ думка зосередилася на пошуках умов і можливостей для виконання барокової музики.

Ванда Ландовська - одна з перших, хто був причетним до становлення феномену «ранньої музики» (Early Music). Вона привертає увагу до того факту, що мало хто з її сучасників ретельно вивчав музику Середньовіччя, Ренесансу, Бароко. А між тим, музична практика цих епох закладає основу для формування стилів і віденського класицизму, і романтизму, і нової музики. Не знаючи витоків європейського музичного мистецтва, неможливо в повній мірі розуміти ту музику, яку було створено в подальшому, оскільки зміни історичних епох відбувалися поступово, і навіть творчість композиторів-новаторів виявляє спадкоємні зв'язки із попередніми епохальними стилями.

Хоча термін «Early Music» стосується, перш за все, музики Ceредньовіччя, Ренесансу, Бароко, інколи його розповсюджують і на музичну практику віденського класицизму і раннього романтизму. Дане поняття при цьому означає не лише музику відповідних епох, а й тенденцію у виконавській практиці, пов'язану з максимально точним відтворенням звучання, яке було характерним для того чи іншого історичного часу, що отримала назву «автентичне виконавство». Остан-

${ }^{3}$ Це Клод Гудимель, Ніколя де Гриньи, Андре Резон, Ніколя Лебег і Луї Маршан, французькі лютністи - династия Готьє, французькі клавесиністи - Жак Шампион де Шамбоньер, Жан Анрі д’Англебер, Луї Куперен.

${ }^{4}$ Всесвітні виставки у Парижі (фр. Exposition universelle de Paris) відбулися 1867, $1878,1889,1900 \mathrm{p}$. 
нє передбачає роботу зі старовинними трактатами і факсимільними нотними виданнями, що дають уявлення про артикуляційні, штрихові, агогічні особливості виконання, орнаментику тощо; застосування відповідного конкретній епосі інструментарію ${ }^{5}$ - відновлення старовинних інструментів або конструювання їх точних копій, створення шкіл і товариств, які спеціалізуються саме на старовинній музиці. В цілому концепція «Early Music» та автентичного виконавства базується на ідеї індивідуального підходу до кожної конкретної епохи, композиторського стилю, музичного твору.

Працюючи над інтерпретацією старовинних творів, В. Ландовська, насамперед, виходила з історичного контексту епохи, загального музичного сенсу і особливої атмосфери старовинної музики. Також вона наголошувала на важливості виконання музики на інструментах саме тієї епохи, для якої вони були написані. У своїх роботах В. Ландовська акцентувала увагу на проблемах відтворення давньої музики на клавесині, а саме, на таких параметрах виконання, як темп, динаміка, регістровка, фразування, орнаментика. Зокрема, В. Ландовська наводить і розбирає таблиці Ф. Куперена, Ж.-Ф. Рамо та І. С. Баха з розшифровками прикрас. 3 останнього витікає і питання про особливості барокової імпровізації, до якого теж звертається В. Ландовська. Вона також приділяє велику увагу вивченню французького та італійського впливу на німецьку музику. В. Ландовська, спираючись на старовинні трактати ${ }^{6}$ (оскільки принципи тієї чи іншої епохи підказують певні особливості виконання й сприйняття музики), прагнула знайти практичне рішення означених проблем саме на автентичних інструментах, оскільки від конструкції останніх в значній мірі залежать техніка й характер виконання.

Таким чином, видатна виконавиця наполягала на зовсім іншому підході до інтерпретації музики минулих епох у порівнянні із тим, що

\footnotetext{
5 Зараз сфера автентичного виконавства настільки розширилася, що музику віденського класицизму і раннього романтизму воліють виконувати на хаммерклавірах, музику Ф. Шопена - на роялях, створених фабрикою Ерара, К. Дебюссі - на різних англійських моделях, які він мав на момент написання своїх творів.

6 Зокрема, I. І. Кванца (2012), К. Ф. Э. Баха (2005).
} 
панував у іï час. Вона вважала, що звернення до музики визначних майстрів минулого дає музикантові можливість розвивати гарний музичний смак та естетичне почуття, а вивчення джерел відповідних епох - створити повноцінне уявлення про старовинну музику. В. Ландовська заклала основи історично інформованого виконавства, наголошуючи на необхідності вивчення музикантами теоретичних праць П. Ф. Тозі-Й. Ф. Агріколи, Й. Й. Кванца, Ф. Куперена, Ж.-Ф. Рамо, Л. Моцарта, Дж. Фрескобальді, Ф. В. Марпурга, К. Ф. Е. Баха і багатьох інших (Ландовска, В., 1991, с. 350).

В. Ландовська здобула визнання у всьому світі як академічна піаністка віртуозного напряму, але при цьому стала ще й знаменитою клавесиністкою. Для неї не було нічого неможливого: чи то виконати «Італійський концерт» I. С. Баха або його ж «Хроматичну фантазію», або весь «ДТК». Вона майстерно виконувала на фортепіано твори Ф. Шопена та інших романтиків, твори віденських класиків, і в той самий час володіла технікою гри на клавесині, невимушено виконуючи п’єси французького Рококо.

В. Ландовська детально вивчила клавірну творчість видатних клавесиністів Ф. Куперена $і$ Ж.-Ф. Рамо. Зберігся унікальний запис 1934 р. виконання нею на клавесині п’єси «Дикуни» Ж. Ф. Рамо. Її гра відрізняється незвичайним розмахом, небувалою пишністю і величчю музичних образів. Цей стиль, створений у Франції спеціально для розкішних палаців епохи Людовіка XIV, в музиці, головним чином, Ж.-Б. Люллі, і відтворила В. Ландовська. Під іï пальцями двомануальний клавесин звучить подібно до концертного роялю; у своєму виконанні вона, як ніхто інший, вміла талановито обігравати зміну афектів: $з$ одного боку, масштабність та урочистість, притаманні музиці Бароко і Рококо, з іншого - камерна інтимність деяких клавесинних мініатюр. Особливу увагу вона приділяла регістровим ефектам на клавесині ${ }^{7}$ для вираження вишуканості і витонченості французької музики, що ілюструє іiї виконання «Дикунів». Спочатку музика

\footnotetext{
${ }^{7}$ Клавесин Ванди Ландовської не був історичною копією і за звучанням сильно відрізнявся від аутентичних інструментів епохи Бароко, його можна назвати гібридом, що поєднує риси клавесина і рояля.
} 
в іiï інтерпретації подібна до стислої пружини (як образ знаменитих сходів Франческо Борроміні ${ }^{8}$ ), що готова в будь-який момент розгорнутися. Її гра викликає асоціації і з урочистим маршем - зі знаменитим турецьким маршем Ж.-Б. Люллі або рондо В. А. Моцарта в турецькому стилі з сонати A-dur. За структурою «Дикуни» Ж.-Ф. Рамо являють собою форму рондо 3 незмінним рефреном. Знаменитий галантний французький стиль особливо підкреслюють інегаліте i загострений пунктир. Клавесинній музиці Ж.-Ф. Рамо властивий крупний штрих, він не схильний до тонкого виписування деталей, його музика відрізняється яскравою характеристичністю, в ній відразу відчувається почерк природженого театрального композитора («Курка», «Дикуни», «Циклопи»). Вивчаючи творчість Ж. Ф. Рамо, В. Ландовська дійшла висновку, що слава його трактатів з музичної теорії перевершує його славу «художника-творця» (1991, с. 258). Між тим, його художня творчість позначила найвищу планку для виконавців і композиторів. В. Ландовська пише, що клавесинні п’єси Ж.-Ф. Рамо - «... за сутністю, майже театральні вистави», створіння генія, сповненого «натхнення і страсті». «Як ще можна охарактеризувати автора “Свят Геби" (“Les Fétés d’Hébé”), “Іпполіта і Аpiciī” ("Hippolyte et Aricie”), “Галантної Індіï” (“Les Indes Galantes”), "Кастора і Полукса” (“Castor et Pollux”) та ще стількох шедеврів?» (Ландовска, В., 1991, с. 258). Створюючи образи барвисті і веселі або урочисті і величні, Ж.-Ф. Рамо, як ніхто інший, міг передати фарбами і відтінками глибину і тонкість ліричного образу. Він насолоджувався щебетом птахів і навколишньою природою і в музиці передавав свої почуття. Ж.-Ф. Рамо стверджував: «перш, ніж природу зображати, їі потрібно вивчити» (там само, с. 258).

Напевно, одне з найтепліших почуттів було виражене у відгуках В. Ландовської про музику Ф. Куперена: «Чому ця музика, відображаючи наш відчай, наповнена в той же час такою розрадою? Тому що вона не тільки виражає наш сум і скорботу, але й підносить страждання. < ..> Піднесеність куперенівської музики окрилює < ..> змушує

\footnotetext{
8 Франческо Борроміні, італ. Francesco Borromini (1599-1667) - великий італійський архітектор, який працював у Римі, радикальний представник раннього Бароко.
} 
нас відгукуватися на хвилювання, змішане 3 таємничою радістю»; «...музика Ф. Куперена торкається сфери підсвідомого» (там само, c. 249). «Широта і благородство ліній, сміливі і чарівні гармонії, напруженість атмосфери і експресія - ось характерні особливості музики Куперена» (там само, с. 248). Дійсно, маючи програмний зміст назвемо, наприклад, такі п’єси, як «Арлекін», «Французькі фолії або маски доміно», «Цнотлива», «Женці», «Щебет» та інші - твори Ф. Куперена відрізняються своєю витонченістю.

Якщо говорити про клавесинізм як яскраве явище музичної культури Франції 17-18 ст., то, звичайно, всі шляхи ведуть до Ф. Куперена $^{9}$. Його твори були в репертуарі В. Ландовської ${ }^{10}$. Одним з основних композиційних типів в творчості Ф. Куперена були п’єси-мініатюри, але не складені в сюїти, як у більшості композиторів, а зіставлені в ряди (ordre), подібно до галереї візуальних і навіть портретних образів. У порівнянні зі своїми попередниками, Ф. Куперен значно ширше користується можливостями клавесина, вільніше розпоряджається звучностями інструменту у всьому його діапазоні, зокрема, використовує два мануали великого клавесину (на них спеціально розраховані п'єси «сroisé», тобто з перехрещенням); всебічно розробляє клавесинну фактуру; активізує голосоведіння, підсилює загальну динаміку в середніх розділах п’єс, надає великої уваги орнаментиці. Все це $з$ великим успіхом демонструвала на своєму багатопедальному клавесині з безліччю регістрів В. Ландовська.

В. Ландовська вважала, що для того, щоб знайти правильний темп, якісний звук, необхідно, перш за все, досконало вивчити механізм інструменту. Вона зауважує: «правильне інтонування інструменту - це вже значна частина мистецтва клавесинної гри, що ... найчастіше ігнорується» (там само, с. 350). Ми можемо говорити з приводу «почуття ритму», «точності і артикуляції звучання» і про «просторові уявлення» тільки з позиції клавесиніста, що грає на клавесині,

9 Клавесинні твори Ф. Куперена (1668-1733) - чотири збірки 1713, 1717, 1722 , 1730 рр. - являють собою одну з вершин французької клавесинної школи. Ним також написаний підручник для клавесиністів-початківців, що вивчається фахівцями досі: «L'art de toucher le clavecin» - «Мистецтво дотику на клавесині» (1716).

${ }^{10}$ Джерело: https://www.youtube.com/watch?v=GuX2e-Ipi_Q 
бо фортепіано всі ці тонко розкреслені межі стирає. У клавесиніста можуть бути інші принципи інтонування на інструменті і зовсім інші аплікатурні рішення (наприклад, без підкладання великого пальця) (Бах, К. Ф. Э., с. 31, 39, 46), а на клавікорді інтонування на вібрато взагалі $є$ одним з основних прийомів технології звуковидобування. Величезне значення має початок та коротка мить, яку необхідно витримати перед взяттям першої ноти ${ }^{11}$.

Добре вивчивши сам твір - його структуру, мелодику, голосоведіння, риторику, танцювальну атрибутику - потім дуже легко додати до нього і якісь виконавські ефекти. Розуміння темпових позначень сильно відрізнялися в різні епохи. Штрихи і відтінки головним чином залежать від інструментарію, на якому виконується даний твір. Один і той же відтінок може виглядати зовсім по-різному, скажімо, на клавесині, на хаммерклавірі, на органі або на фортепіано, а штрихи повністю залежать не тільки від особливостей інструменту, але і від вибору аплікатури.

Вміння мислити і говорити тією мовою, якою написано той чи інший старовинний твір, дає виконавцю творчу свободу і артистизм, тільки вже більш високого рівня, ніж просто оволодіння зручною аплікатурою або штрихами. Щоб втілити в звуках своє бачення музики, виконавець повинен мати гарний смак, на цьому наполягає В. Ландовська (1991, с. 387, 389 та ін.), але останній має бути пов’язаний зі знанням матеріалу, стилів минулого та історичного контексту. «Сьогоднішні музиканти, особливо виконавці, прокладають свій шлях в царстві старовинної музики так, ніби потрапили на невідому землю. Вони не наважуються ризикнути використати метафору або образність - якою б підходящою вона їм не здавалася. Туманне уявлення про фарби і характер тієї епохи зупиняє їх на кожному кроці і робить боязкими» (там само, с. 391). В. Ландовська приділяє смаку і помір-

11 Цьому багато уваги приділяли і аутентисти наступних поколінь, такі, як Густав Леонхардт, П'єр Антай, Жорді Саваль, Аннер Більсма, Ніколаус Арнонкур, Франц Брюгген, Ендрю Перрот, Брюно Коксе та інші. Слід сказати, що увага історичних виконавців до цезур і знаків пунктуації в музиці і майстерність побудови музичної фрази доведені до такої досконалості, що і тактова риса теж стає одиницею часу, з якою, як і з паузою, не рахуватися не можна. 
ності в намірах велику увагу. Вона має в цьому і своїх ідейних послідовників, як наприклад, Г. Леонхардта, який застерігав від частого і надмірного використання геміол або занадто манірного виконання iнегаліте $^{12}$ (Чалог, Б., 2017). Для того, щоб досягти чистоти звучання кожного голосу, необхідно правильно підібрати регістр, тому що під час виконання міняти регістр не можна - порушується безперервність, плинність фрази. Зловживання частими, строкатими відтінками і зайва поспішність у виконанні говорять про поганий смак.

У своїй роботі В. Ландовська торкається основного ключа до старовинної музики - риторики. Вона пише: «Розділяти мелодичну лінію цезурами, що диктуються логікою, імпульсом, фантазією, дозволяти повітрю циркулювати - це споріднене із диханням <.. > Ось чому всі старовинні трактати порівнюють музичну інтерпретацію 3 риторикою» (там само, с. 363). Важливу роль в інтерпретації слід приділити фразуванню і диханню, яке грає головну роль, оскільки кожна пауза, цезура логічно розділяє мелодичну лінію, і вона повинна бути дослуханою, щоб надати твору контури, виразність для чіткого уявлення змісту п’єси (там само). В. Ландовська підкреслює, що нюанси, навіть дрібні, є дуже важливими, так як можуть змінити фразу до невпізнання: те, що для академічного музиканта є чимось незначним, для автентичного музиканта є дуже значущим, звідси і унікальність автентичного трактування.

Особливістю виконання В. Ландовської є зважене відношення до ритмічної свободи, оскільки гра на клавесині примушує виконавця думати і чути по-іншому. Вона пише: «Критики нападають на мене за те, що я не граю ноту з крапкою в темі першої фуги “Добре темперованого клавіру”, за те, що не завжди звертаю увагу на лігу там, де вона відзначена, і головним чином, за те, що додаю прикраси і ритмічні зміни <.. > . Існує велика різниця між вольностями, що вимагалися від виконавця в XVII-XVIII століттях, і сучасними транскрипціями піаністів, які поняття не мають про те, що це були за свободи» (Ландовська, 1991, с. 387). Тобто ритмічна свобода не має бути синонімом сва-

12 Інегаліте (фр.) - нерівність; неодна́ковість; у музиці- манірне нерівне виконання сильних і слабких часток, зовні однаково записаних (Чалог, Б., 2017). 
вілля: «Особливістю мого виконання, котра, як мені говорили, вражає слухача, є точність, з якою я передаю довгості нот. Вражати це може лише тому, що занадто часто доводиться шкодувати про відсутність такої точності. Вірне відчуття довгостей та їх взаємозв'язків - одне 3 найтрудніших питань викладання» (там само, с. 365). Отже: «Одні фрази всередині п'єси потребують ритмічних змін, тоді як інші - ні» (там само, с. 373).

Вивчаючи старовинні трактати, В. Ландовська зробила певні висновки: технологія гри на інструменті набагато складніше і багатогранніше, ніж просто шліфування «складних пасажів», як це вважають сьогодні, а «технікою» в ту епоху називалася «координація думки і пальців» (там само, с. 150). В. Ландовська пише, що використовує абсолютне легато, як того вимагає клавесинне туше: «Якщо туше недостатньо злите, страждає і випаровується звучність <...> завдяки певній тяжкості туше виявляються дисонанси, зіткнення, а також гармонічна наповненість» (там само, с. 362). Тут, з одного боку, можна з нею погодитися, так як багато піаністів, виконуючи І. С. Баха, Д. Скарлатті або Ж.-Ф. Рамо та Ф. Куперена на фортепіано, починають імітувати клавесин. Вони використовують так званий «бахівський штрих», non legato iз більш чіткими жорсткими пальцями, i, природно, втрачають легато і інтонаційний зв'язок між нотами. 3 іншого боку, стосовно дисонансів, як видається, краще враховувати досвід більш пізнього часу: дисонанси повинні виявлятися не за рахунок тяжкості (як рекомендує В. Ландовська), а за рахунок затримки часу, відведеного на їх виконання, як роблять Густав Леонхардт, П'єр Антай та інші клавесиністи наступних поколінь.

Загалом, В. Ландовська «вуха» і «свідомість» ставить вище просто хорошої координації пальців; завдання автентиста складніше пов'язати в єдине ціле не тільки апарат, але і все в цілому: і туше, і ритм, і дихання, і агогіку, і орнаментику, і спів, і танець, і риторику, і символіку, і звук, і тембр, і темперацію. Будь-який технологічний нюанс веде до слуху і до внутрішнього слуху, тобто до іншого слухового досвіду і «вміння чути» $\mathrm{i}$ «чути по-іншому». «Причина нерівності [туше] криється у вухах, а не в пальцях. <..> якщо вуха не слухають, як можна чекати, що пальці будуть діяти?» (там само, с. 363). 
Висновки. В. Ландовська позиціонувала себе здебільшого як клавесиністка, популяризувавши цей інструмент, хоча звучання ii клавесина є ще досить далеким від звучання «історичного клавесина», наприклад, Г. Леонхардта. Тим не менш, для сучасників В. Ландовської відтворене нею звучання клавесина було приголомшливим. Як результат, вона повністю змінила тогочасні виконавські й слухацькі уявлення про старовинну музику, надавши міцного поштовху до повного перегляду і переосмислення загальноприйнятих манер виконання і романтичних слухових кліше. Її підхід до ревізії всієї музичної спадщини з точки зору автентизму можна порівняти хіба що з народженням і найбільшим зльотом в ті ж роки такого напряму наукової думки, як герменевтика. П'ятдесятирічний практичній досвід В. Ландовської-клавесиністки є дуже важливим і необхідним і для сучасних виконавців старовинної музики, які прагнуть до максимально точного відтворення шедеврів майстрів XVII-XVIII ст., що обумовлює перспективність подальшого поглибленого вивчення творчого спадку видатної артистки й дослідниці.

\section{ЛІТЕРАТУРА}

Арнонкур, Н. (2002). Музыка языком звуков. Путь к новому пониманию музыки. Сумы: Собор, 184.

Бах, К. Ф. Э. (2005). Опыт истинного искусства клавирной игры. Книга первая. 1753 г. Е. Юшкевич (Пер., коммент.). Санкт-Петербург: Early music, 169.

Вєркіна, Т. Б. (2008). Актуальне інтонування як виконавська проблема. (Автореф. дис. ... канд. мистецтвознавства). Національна музична академія України імені П. І. Чайковського. Київ.

Кванц, И. И. (2013). Опыт наставлений в игре на флейте траверсо. Санкт-Петербург: Фонд Возрождения Старинной Музыки, 392.

Курковський Г. (1983). Клавесиністка і піаністка Ванда Ландовська. В кн.: Питання фортепіанного виконавства, сс. 79-89. Київ: Музична Україна.

Ландовская, В. (1991). О музыке. Д. Ресту (Сост.); А. Майкапар (Пер. с англ., послесл.). Москва: Радуга, 438. 
Майкапар, А. (1991). Слово о Ванде Ландовской. В кн. Ландовская, В. (1991). О музыке. Д. Ресту (Сост.); А. Майкапар (Пер. с англ., послесл.), сс. 396-401. Москва: Радуга.

Оссовский, А. (1971). В. Ландовска и старинная музыка. В кн.: А. В. Оссовский. Музыкально-критические статьи (1894-1912). Ленинград: Музыка, 205-208.

Свириденко, Н. С. (2010а). Ванда Ландовська та ії відкриття старовинної музики (до 130-річчя від дня народження та 50-річчя від дня смерті). Мистеитвознавчі записки, 17, 267-273. Київ.

Свириденко, Н. С. (2010b). Книга Ванди Ландовської «Старовинна музика». Актуальні проблеми історії, теорії та практики художньої культури, 24, 324-332. Київ.

Свириденко, Н. С. (2017). Стилістика виконання старовинної музики на прикладі творів Й. С. Баха. (Навч.-метод. посібник для студ. ВНЗ). Київ: Київський університет імені Б. Грінченка. 242.

Чалог, Б. (2017). Инегаль в музыке Барокко, ч. 1, лекция Бенедека Чалога в МГК, ноябрь 2017. Retrieved from https://www.youtube. com/watch? $v=$ DufAgWHnexo

Швейцер, А. (1965). Иоганн Себастьян Бах. Я. С. Друскин (Пер. с нем.) Москва: Музыка, 724.

Kottick, E. L. (2003). A history of the harpsichord. Bloomington: Indiana University Press, XVI\&557 p.

Salter, L. Landowska, Wanda. Grove Music Online. Oxford Music Online. Oxford University Press. Retrieved April 25, 2019, from https:// doi.org/10.1093/gmo/9781561592630.article.15951

Swain, J. P. (2013). Historical Dictionary of Baroque Music. Lanham; Toronto; Plymouth, UK: The Scarecrow Press, Inc., 394.

\section{REFERENCES}

Bach, C. Ph. E. (2005). Opyt istinnogo iskusstva klavirnoy igry [The experience of true art of the clavier playing]. Book 1, 1753. E. Yushkevich (Transl., comment.). St. Petersburg: "Early Music" Publishing House, 169 [in Russian].

Csalog, B. (2017). Inegal $\mathrm{v}$ muzyke Barokko, ch. 1, lektsiya Benedeka Chaloga v MGK, noyabr 2017 [Inégale in Baroque music, part 1, 
the lection by Benedek Csalog in Moscow State Conservatory, Novemder 2017]. Retrieved from https://www.youtube.com/watch?v=DufAgWHnexo [in English].

Harnoncourt, N. (2002). Muzyka yazykom zvukov. Put $k$ novomu ponimaniyu muzyki [Music by the language of sounds. The way to a new understanding of music]. (Transl. from German). Sumy: Sobor, 184 [in Russian].

Kottick, E. L. (2003). A history of the harpsichord. Bloomington: Indiana University Press, XVI \& 557 p.

Kurkovskyi, H. (1983). Klavesynistka i pianistka Vanda Landovska [Harpsichordist and pianist Wanda Landowska]. In Pytannia fortepiannoho vykonavstva-Questions of piano performing, pp. 79-89. Kyiv: Muzychna Ukraina.

Landowska, W. (1991). O muzyke [About Music]. (D. Restout, comp.; A. Maikapar, transl., afterword). Moscow: Raduga, 439 [in Russian].

Maikapar, A. (1991). Slovo o Vande Landovskoy. [The Word about Vanda Landowska]. In Landowska, V. (1991). O muzyke [About Music]. (D. Restout, comp.; A. Maykapar, transl., afterword), pp. 396-401. Moscow: Raduga [in Russian].

Ossovskiy, A. V. (1971). V. Landovska i starinnaya muzyka [Wanda Landowska and early music]. A. V. Ossovskiy. Muzykalnokriticheskie stati (1894-1912) - Music critical articles (1894-1912). Leningrad: Muzyka, 205-208 [in Russian].

Quantz, J. J. (2013). Opyt nastavleniya po igre na fleyte traversiere [The experience of the guidance in Flute 'traversiere' playing]. St. Petersburg: Fond Vozrozhdeniya Starinnoy Myzyki, 392 [in Russian].

Salter, L. Landowska, Wanda. Grove Music Online. Oxford Music Online. Oxford University Press. Retrieved April 25, 2019, from https:// doi.org/10.1093/gmo/9781561592630.article.15951

Schweitzer, A. (1965). J. S. Bach. Ya. S. Druskin (Transl. from German). Moscow: Muzyka, 724 [in Russian].

Svyrydenko, N. S. (2010). Knyha Vandy Landovskoi «Starovynna muzyka» [Wanda Landowska's book "Ancient Music"]. Aktualni problemy istorii, teorii ta praktyky khudozhnoi kultury - Actual Problems of Art History, Theory and Practice, 24, 324-332. Kyiv [in Ukrainian]. 
Svyrydenko, N. S. (2010). Vanda Landovska ta yii vidkryttia starovynnoi muzyky (do 130-richchia vid dnia narodzhennia ta 50-richchia vid dnia smerti) [Wanda Landowska and her discovery of ancient music (up to 130th from birthday and 50th anniversary from death date)]. Mystetstvoznavchi zapysky - Art Studies Notes, 17, 267-273. Kyiv [in Ukrainian].

Svyrydenko, N. S. (2017). Stylistyka vykonannia starovynnoi muzyky na prykladi tvoriv I. S. Bakha [Stylistics of performing of the ancient music on the example of J. S. Bach's works]. (Study methodical guide for university students). Kyiv: Kyivskyi universytet imeni B. Hrinchenka [B. Hrinchenko University of Kyiv], 242 [in Ukrainian].

Swain, J. P. (2013). Historical Dictionary of Baroque Music. Lanham; Toronto; Plymouth, UK: The Scarecrow Press, Inc., 394.

Vierkina, T. B. (2008). Aktualne intonuvannia yak vikonavska problema [Actual intonating as a performing problem]. (Extended abstract of Candidate's thesis). National Music Academy of Ukraine named after P. I. Tchaikovsky. Kyiv [in Ukrainian]. 